\title{
Investigation of the Peripheral Analgesic Activity of Oxicams and Their Combinations with Caffeine
}

\author{
Oksikamların ve Kafein ile Kombinasyonlarının Periferal Analjezik \\ Aktivitelerinin İncelenmesi
}

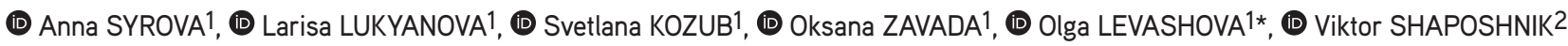 \\ ${ }^{1}$ Kharkiv National Medical University, Department of Medical and Bioorganic Chemistry, Kharkiv, Ukraine \\ 2Kharkiv National Medical University, Kharkiv, Ukraine
}

\begin{abstract}
Objectives: Therapy of pain syndromes involves exposure to its source, receptors, and peripheral fibers. Treatment of acute pain and inflammation involves the use of nonsteroidal anti-inflammatory drugs and nonnarcotic analgesics. An alternative to obsolete analgesics is combined compositions. Experimental results clearly indicates that caffeine effectively enhances the peripheral analgesic activity when combined in an analgesic. The aim of the present study was to evaluate the peripheral analgesic activity of meloxicam, piroxicam, and their pharmacological combinations with caffeine. Materials and Methods: The peripheral analgesic activity of piroxicam, meloxicam, and their combinations with caffeine was studied using the abdominal writhing test. This method was used to induce pain of peripheral origin by intraperitoneal injection of $0.6 \%$ acetic acid solution. The investigated drugs, their combinations, and $3 \%$ starch mucilage were administrated $1 \mathrm{~h}$ before the introduction of the algogen. The cumulative number of writhing responses induced by acetic acid was determined over the subsequent 20 min.

Results: All investigated drugs supplied a decrease in writhing in rats. Meloxicam and caffeine showed peripheral analgesic activity of $63.6 \%$ and $64.5 \%$, respectively $(p<0.05$ ). The pharmaceutical combination of meloxicam and caffeine showed analgesic potential of $76.4 \%$. Thus, caffeine potentiates the analgesic activity of meloxicam. The results exceeded the corresponding value of diclofenac sodium (67.3\%).

Conclusion: Experimental results clearly indicates that caffeine effectively enhances the peripheral analgesic action of meloxicam when combined in a pharmaceutical composition. These results can serve as a basis for the development of new domestic combined drugs.
\end{abstract}

Key words: Meloxicam, piroxicam, caffeine, pharmaceutical composition, analgesic activity

ÖZ

Amaç: Ağrı sendromlarının tedavisi, ağrı kaynağına maruziyeti, reseptörleri ve periferal lifleri içermektedir. Akut ağrı ve enflamasyonunun tedavisi, nonsteroidal anti-enflamatuvar ilaçların ve narkotik olmayan analjeziklerin kullanımını içerir. Eski analjeziklere bir alternatif kombine bileşimlerdir. Deneysel sonuçlar kafeinin bir analjezik ilaç ile birleștirildiğinde, peripheral analjezik aktiviteyi etkin bir şekilde artırdığını açıkça göstermektedir. Bu çalışmanın amacı, meloksikam, piroksikam ve bunların kafeinle farmakolojik bileşimlerinin periferal analjezik aktivitesini değerlendirmektir.

Gereç ve Yöntemler: Piroksikam, meloksikam ve bunların kafeinle bileşimlerinin periferal analjezik aktivitesi abdominal ağrı testi kullanılarak incelenmiștir. Bu yöntem, periferik orijinli ağrının oluşturulmasında \%0,6'lık asetik asit çözeltisinin intraperitonel olarak enjekte edilmesiyle ağrının indüksiyonunu sağlamak için kullanılmıştır. İncelenen ilaçlar, bunların bileşimleri ve \%3 nişasta müsilajı, algojenin verilmesinden 1 saat önce uygulanmıştır. Asetik asit tarafından indüklenen kümülatif ağrı cevapları, sonraki 20 dakika boyunca belirlenmiştir.

Bulgular: İncelenen tüm ilaçlar, sıçanlarda ağrı azalması sağlamıştır. Meloksikam ve kafein periferal analjezik aktivitelerini sırasıyla \%63,6 ve \%64,5 olarak göstermiştir ( $p<0,05$ ). Meloksikam ve kafeinin farmasötik bileşimi \% 76,4'lük analjezik potansiyel göstermiştir. Bu nedenle kafein, meloksikamın analjezik aktivitesini potansiyeize etmektedir. Sonuçlar diklofenak sodyumla elde edilen değerden (\%67,3) fazladır.

Sonuç: Deneysel sonuçlar açıkça kafeinin meloksikamla farmasötik bileşiminin meloksikamın periferal analjezik etkisini etkin bir şekilde arttırdığını göstermektedir. Bu sonuçlar yeni yerli kombine ilaçların geliştirilmesinde temel oluşturabilir.

Anahtar kelimeler: Meloksikam, piroksikam, kafein, farmasötik bileşim, analjezik aktivite

*Correspondence: E-mail: olga.jdan78@gmail.com, Phone: +380577077307 ORCID-ID: orcid.org/0000-0001-9779-7762

Received: 30.09 .2018 , Accepted: 18.07.2019

๑Turk J Pharm Sci, Published by Galenos Publishing House. 


\section{INTRODUCTION}

Nonsteroidal anti-inflammatory drugs (NSAIDs) and nonnarcotic analgesics (NNAs) are widely used for the treatment of inflammation and pain syndromes. Analysis of the scientific literature has shown that polycomponent compositions are more effective than monopreparations in treating pain. Therefore, the development of new effective domestic multicomponent drugs with a minimum number of side effects is a very important subject.1.-4

It is known that caffeine improves the analgesic effect of NNAs. The mechanism of potentiation of analgesic effects is associated with an improvement in NNA bioavailability in combinations with caffeine and with the effect of caffeine on adenosine receptors (so-called purine analgesia). ${ }^{5-9}$ Research on the biological effects of caffeine and its pharmacological combinations showed a positive effect on the central nervous system. Caffeine shows a wide range of action: reduction in adenosine transmission, regulation of excitation processes in the cerebral cortex, and in corresponding doses it enhances positive condition reflexes and increases motor activity. ${ }^{10-13}$

The aim of our work was the experimental investigation of the peripheral analgesic activity of oxicams (meloxicam and piroxicam), caffeine, and their pharmacological combinations.

\section{MATERIALS AND METHODS}

An experimental study of analgesic activity was conducted on laboratory animals, namely mature rats. The peripheral analgesic activity was studied by the changes in the nociceptive reactions of the rats. The comparative characteristic of the analgesic activity of meloxicam, piroxicam, caffeine, and their pharmacological combinations was studied using an acetic acid-induced abdominal writhing test. Writhes were caused by a single intraperitoneal injection of $0.6 \%$ acetic acid solution ( 1 $\mathrm{mL}$ per $100 \mathrm{~g}$ of animal weight) in rats. The investigated drugs, their combination, and $3 \%$ starch solution were injected $1 \mathrm{~h}$ before the algogen was introduced. Then the number of writhes was counted for $20 \mathrm{~min}^{14}$

The animals were divided into 7 groups with 6 animals in each. In the first group $3 \%$ starch mucus ( $2 \mathrm{~mL}$ per $200 \mathrm{~g}$ of the rats weight) was injected via a gastric tube into intact animals. The experimental drugs and their combinations were administered to the animals in groups 2-7 once via a gastric tube: animals in the second group received piroxicam (1.3 mg per $1 \mathrm{~kg}$ of animal weight), the third group meloxicam $(0.6 \mathrm{mg}$ per $1 \mathrm{~kg}$ of animal weight), the fourth group caffeine $(0.6 \mathrm{mg}$ per $1 \mathrm{~kg}$ of animal weight), the fifth group the combination of piroxicam $(1.3 \mathrm{mg}$ per $1 \mathrm{~kg}$ of animal weight) and caffeine $(0.6 \mathrm{mg}$ per $1 \mathrm{~kg}$ of animal weight), the sixth group the combination of meloxicam (0.6 $\mathrm{mg}$ per $1 \mathrm{~kg}$ of animal weight) and caffeine $(0.6 \mathrm{mg}$ per 1 $\mathrm{kg}$ of animal weight), and the seventh group a reference drug, diclofenac sodium ( $8 \mathrm{mg}$ per $1 \mathrm{~kg}$ of animal weight).

Analgesic activity was estimated by the ability of oxicams (meloxicam and piroxicam), caffeine, their pharmacological combinations, and sodium diclofenac to reduce the number of writhes in the experimental animal groups as compared to the control group and expressed as a percentage by the formula

$$
A A=\frac{C_{c}-C_{e}}{C_{c}} \times 100 \%
$$

where $A A$ : Analgesic activity \%;

$\mathrm{C}_{\mathrm{c}}$ : The average number of writhes in the control group;

$\mathrm{C}_{\mathrm{e}}$ : The average number of writhes in the experimental group (9-10).

In addition, the analgesic activity of oxicams and caffeine was compared with that of their combinations (meloxicam + caffeine and piroxicam + caffeine) and the reference drug.

The study was carried out in accordance with the methodological recommendations of the State Pharmacological Center of the Ministry of Health of Ukraine ${ }^{14,15}$ and approved by the Ethics Committee of Kharkiv National Medical University (KhNMU). An economical approach, bioethical rules, and statistics requirements were considered when choosing the number of animals and their allocation to the treatment groups.

The study was performed on laboratory animals from the experimental biological clinic of KhNMU. The rats were housed under the strict norms for storage, care, and feeding according to the principles of the "European Convention for the Protection of Vertebrate Animals used for Experimental and other Scientific Purposes" (Strasbourg, 1986) the First National Congress on Bioethics (Kyiv, 2007). ${ }^{18}$ Room temperature was maintained at $23-25^{\circ} \mathrm{C}$, room lighting was 100 $\mathrm{Ix}$, and the animal cage lighting was 20-40 Ix. The laboratory animals were housed for 1.5 months, the acclimatization period was 2 weeks, the main diet was vegetables and fodder beet, and the source of water was settled tap water. The experiments were carried out in the morning, which, according to the literature data, corresponds to the dependence of the main pharmacological parameters and pharmacological activity of investigated drugs on circadian rhythms. ${ }^{19-21}$

\section{Statistical analysis}

Statistical calculations were performed by conventional methods using the programs MS Excel and Statgraphics Plus $2 . .^{22}$

\section{RESULTS AND DISCUSSION}

A specific pain response was investigated by the method of chemical peritoneal irritation. There are several known methods of specific pain investigation: acetylcholine writhes and acetic acid-induced abdominal writhing tests. "Stretching" of animals in the acetylcholine writhing model caused by activation of the arachidonic acid metabolism with COX results in increased synthesis of prostaglandins under the influence of acetylcholine. The mechanism of acetic acid-induced pathology activates the kinin-kallikrein system, prostaglandins, biogenic amines, and leukotrienes, which are endogenous inflammatory mediators and contribute to the development of the abdominal muscle spasm, accompanied by the retraction of the hind paws and the back flexes. The effect of the investigated substances 
on the peripheral component of the nociceptive response was examined by the acetic acid abdominal writhing test, as the most informative method.

In our previous studies, the central analgesic activity of caffeine in combination with piroxicam and meloxicam was studied in order to create a new medicinal composition.

The results of experimental studies have shown that administration of piroxicam, meloxicam, and caffeine monopreparations reduces the number of writhes 2-, 2.6-, and 2.8-fold, respectively, compared to the control group and produces a result similar to that of the reference drug (Figure 1).

Such a result for caffeine peripheral analgesic activity may be associated with inhibition of prostaglandin synthesis and the transient receptor potential channel subfamily A member 1 channel, which acts as the main receptor of neuropathic pain of peripheral origin. Caffeine also helps to eliminate exudate from the area of inflammation and, accordingly, reduces the compression of peripheral nociceptors. This is confirmed by our studies on the anti-exudative effect of the above-mentioned compositions with caffeine. ${ }^{13}$

The analgesic activity of piroxicam (53.6\%) and caffeine (64.5\%) monopreparations has values similar to that of the reference drug, diclofenac sodium (67.3\%). The combination of piroxicam with caffeine shows a reduction in writhes of 1.7 -fold and has the lowest value of analgesic activity, $40.9 \%$. Piroxicam, as a nonselective inhibitor of cyclooxygenase (COX1 and COX-2), has a rapid and pronounced analgesic effect. The selectivity index (inhibition ratio COX-1/COX-2) is 33, i.e. it has the highest potency against COX-1. However, a literature review of nonselective NSAIDs' effects indicates that the concomitant use of piroxicam with a preparation having an antiedemic action (caffeine) might reduce their effect. This effect could be attributed to the NSAID inhibition of renal prostaglandin synthesis and increased fluid retention. Coadministration of piroxicam with caffeine may show antagonism due to their pharmacokinetic properties. Additionally, the high affinity of caffeine to blood proteins could be a reason for the antagonistic effect of this composition component on the peripheral analgesic effect. ${ }^{2}$

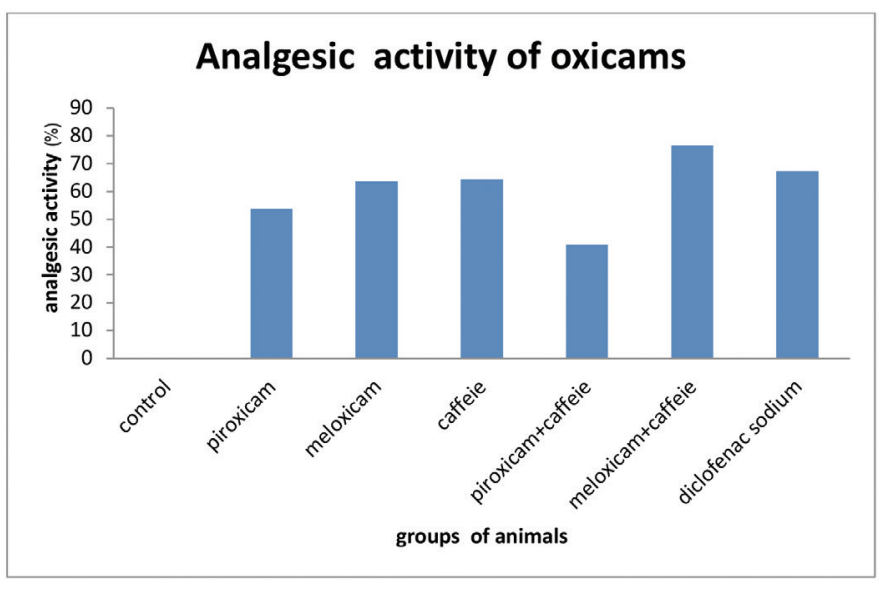

Figure 1. Analgesic activity of oxicams
The addition of caffeine to piroxicam facilitates mitigation of analgesic activity and so this combination shows unpromising results in relation to analgesic activity of peripheral genesis. Contrasting data were obtained by adding caffeine to meloxicam. The meloxicam and caffeine composition has the highest value of analgesic activity, $76.4 \%$, and reduces the number of writhes 4.2-fold.

Meloxicam is a representative of the new generation of NSAIDs, i.e. selective COX-2 inhibitors. The selectivity index (inhibition ratio of COX-1/COX-2) is 0.33 ; it selectively inhibits the formation of prostaglandins involved in the formation of inflammation and has a much lower effect on the synthesis of prostaglandins that regulate renal blood flow, production of protective mucus in the stomach, and platelet aggregation. It is known that selective COX-2 inhibitors doses in which selectivity is observed do not show a sufficient clinical effect. Increasing the dose leads to a loss of selectivity and the appearance of gastrotoxicity. ${ }^{3}$

Our research shows that meloxicam and its combination with caffeine in a lower dose $(0.6 \mathrm{mg})$ than piroxicam $(1.3 \mathrm{mg})$ and even the reference drug $(8 \mathrm{mg}$ ) exhibit higher analgesic activity. The increased analgesic effect of meloxicam combined with caffeine could be explained by the effect of caffeine on the bioavailability of meloxicam and the synergetic effect of these two components. The results indicate potentiation of analgesic activity of the last one; therefore, this composition is considered promising for further study (Table 1).

$\begin{aligned} & \text { Table } 1 . \text { The investigated peripheral analgesic activity of oxicams } \\
& \text { (meloxicam and piroxicam), caffeine and their pharmaceutical } \\
& \text { compositions with caffeine }\end{aligned}$
\begin{tabular}{llll} 
No & Groups of animals & Number of writhes & $\begin{array}{l}\text { Analgesic } \\
\text { activity, } \%\end{array}$ \\
\hline 1 & Control & $22.00 \pm 0.856$ & - \\
\hline 2 & Piroxicam & $10.20 \pm 0.167^{1 / 3 / 4 / 5 / 6 / 7}$ & 53.6 \\
\hline 3 & Meloxicam & $8.30 \pm 0.211^{1 / 2 / 5 / 6 / 7}$ & 63.6 \\
\hline 4 & Caffeine & $7.80 \pm 0.477^{1 / 2 / 5 / 6}$ & 64.5 \\
\hline 5 & Piroxicam + caffeine & $13.00 \pm 0.365^{1 / 2 / 3 / 4 / 6 / 7}$ & 40.9 \\
\hline 6 & Meloxicam + caffeine & $5.20 \pm 0.167^{1 / 2 / 3 / 4 / 5 / 7}$ & 76.4 \\
\hline 7 & Diclofenac sodium & $7.20 \pm 0.167^{1 / 2 / 3 / 5 / 6}$ & 67.3 \\
\hline
\end{tabular}

Note: Investigation of peripheral analgesic activity of oxicams and its combination with caffeine shows that the difference is statistically significant:

${ }^{1}$ Reliability of results in relation to the control group, $p<0.05$;

${ }^{2}$ Reliability of results with respect to the monopreparation of piroxicam, $p<0.05$;

${ }^{3}$ Reliability of results with respect to the monopreparation of meloxicam, $p<0.05$;

${ }^{4}$ Reliability of results with respect to the monopreparation of caffeine, $p<0.05$;

${ }^{5}$ Reliability of results with respect to the combination of piroxicam with caffeine, p<0.05;

${ }^{6}$ Reliability of results with respect to the combination of meloxicam with caffeine, p<0.05;

${ }^{7}$ Reliability of results with respect to the monopreparation of diclofenac sodium, $\mathrm{p}<0.05$

\section{CONCLUSION}

1. Meloxicam (dose: $0.6 \mathrm{mg} / \mathrm{kg}$ ) shows peripheral analgesic activity $(63.6 \%)$ at the level of the reference drug (diclofenac sodium) (67.3\%). 
2. Meloxicam in a lower dose $(0.6 \mathrm{mg} / \mathrm{kg})$ than piroxicam $(1.3$ $\mathrm{mg} / \mathrm{kg}$ ) demonstrates higher peripheral analgesic activity, $63.6 \%$ and $53.6 \%$, respectively.

3. The peripheral analgesic activities of piroxicam (53.6\%) and caffeine (64.5\%) monopreparations have higher values than their pharmaceutical combination (40.9\%). Hence, further study of the analgesic activity of piroxicam combined with caffeine is considered inexpedient.

4. The pharmacological combination of meloxicam with caffeine demonstrated pain inhibition of $76.4 \%$, which significantly exceeded the peripheral analgesic activity of the reference drug, diclofenac sodium, $67.3 \%$, i.e. caffeine effectively potentiates the analgesic activity of meloxicam. Thus, the combination of meloxicam with caffeine as a commercial source of a domestic analgesic drug could be subjected to further study.

Conflicts of interest: No conflict of interest was declared by the authors. The authors alone are responsible for the content and writing of the paper.

\section{REFERENCES}

1. Laurence DR, Bennett PN, Brown MJ: Inflammation, arthritis and non-steroidal anti-inflammatory drugs (NSAIDs). Moscow: Medicine. 1991;485-523.

2. Bilousov YuB. Clinical pharmacology and pharmacotherapy: A guide for physicians. Moscow: Medical News Agency. 1997;531. https://www. twirpx.com/file/291957/

3. Weir MR. Renal effects of nonselective NSAIDs and coxibs. Cleve Clin J Med. 2002;69(Suppl 1):53-58.

4. Kozachok NN, Seluk MN, Bychkova SA. Optimalniy vibor nesteroidnogo protivivospalinelnogo preparata $v$ sovremennoy klinicheskoy praktike. News of medicine and pharmacy. 2007;8:3-4

5. Zupanets IA, Nalotov SV, Viktorov AP, editors. Clinical pharmacology. Kharkov: NUPh; 2005.

6. Burchinsky SG. Clinical and pharmacological aspects of the choice of analgesic. Comparative analysis of the paracetamol effectiveness and safety. Pharmacologic Visnik. 2000;354:12-17.

7. Nasonov EL. Nonsteroidal anti-inflammatory drugs: Prospects of use in medicine. Anko. 2000;143:1-2.
8. Chekman I, Gorchakova N, Zvyagintseva T, Syrova G, Nebesna N. Coffeine: Physiological, biochemical and quantum-pharmacological properties. Bulletin of Pharmacology and Pharmacy. 2009;259:2-7.

9. Syrova GO, Zvyagintseva TV. Study of potentiating analgesic properties of caffeine in the experiment. XII Congress of the World Federation of Ukrainian Drug Societies. Ivano-Frankivsk. 2008;454.

10. Sawynok J. Caffeine and pain. Pain. 2011;152:726-729.

11. Sawynok J, Yaksh TL. Caffeine as an analgesic adjuvant: a review of pharmacology and mechanisms of action. Pharmacological Reviews. 1993;45:43-85.

12. Fisone G, Borgkvist A, Usiello A. Caffeine as a psychomotor stimulant: mechanism of action. CMLS. 2004;61:857-872.

13. Syrova GO, Lukianova LV, Chalenko NM. The experimental research on the antiinflammatory action of the new piroxicam-caffeine pharmaceutical composition. Science Review. 2018;4:72-76.

14. Stefanov OV. Preclinical research of medicines: methodological recommendations. Kiiv: Avicenna. 2001;431-432.

15. Trinus FP, Klebanov BM, Kondratyuk VI, editors. Methodical recommendations for the experimental (preclinical) study of nonsteroidal anti-inflammatory pharmacological substances. Moskow; 1983.

16. Burkatskaya EN, Beyer VF, editors. Methodical recommendations on the use of behavioral reactions of animals in toxicological studies. Kiev;1980;47.

17. European convention for the protection of vertebrate animals used for experimental and other scientific purposes: Council of European. Strasbourg, 1986;51:29-34.

18. Kundiev YUI, editor. Modern problems of bioethics. Kiev: Akademperiodica, 2009;278:141-173

19. Drogovoz SM, Rapoport SI, Kononenko AV. Informative chronopharmacology (chronopharmacology in tables and figures): a textbook. Kharkov, Titule. 2014; 128:111-117.

20. Dorogoy AP. To the question of chronopathology, chronotherapy and chronopharmacology in cardiology: Actual problems in modern therapy. Kharkiv. 1992;354:22-25.

21. Zapadnyuk IP, Zapadnyuk VI, Zakharia EA. Laboratory animals: breeding, content, use in experiment ( $3^{\text {rd }}$ ed). Revised and additional. Kiev: Vishcha sckola. Head Publishing House. 1983;383:141-154.

22. Glanc S. Medico-biological statistics. Moscow: Practica. 1998;459:318323. 